STOMACH

\title{
Effect of peroxisome proliferator activated receptor $\gamma$ ligands on growth and gene expression profiles of gastric cancer cells
}

\author{
W K Leung, A H C Bai, V Y W Chan, J Yu, M W Y Chan, K-F To, J-R Wu, K-K Chan, Y-G Fu, \\ F K L Chan, J J Y Sung
}

Gut 2004;53:331-338. doi: 10.1136/gut.2003.021105

See end of article for authors' affiliations

...................

Correspondence to: DrW K Leung, Department of Medicine and Therapeutics, Prince of Wales Hospital, Shatin, Hong Kong; wkleung@ cuhk.edu.hk

Accepted for publication 18 September 2003

\begin{abstract}
Background and aims: Although peroxisome proliferator activated receptor $\gamma$ (PPAR $\gamma$ ) agonists have been implicated in differentiation and growth inhibition of cancer cells, the potential therapeutic and chemopreventive effects on gastric cancer are poorly defined. We examined the in vitro and in vivo effects of PPAR $\gamma$ ligands on growth of gastric cancer, and the effect of PPAR $\gamma$ activation on expression of cyclooxygenase 2 (COX-2) and cancer related genes.

Methods: Gastric cell lines (MKN28 and MKN45) were treated with two specific PPAR $\gamma$ ligands: ciglitazone and 15-deoxy- $\Delta^{12,14}$-prostaglandin $J_{2}$. Cell growth was determined by bromodeoxyuridine incorporation assay and apoptosis was measured by DNA fragmentation. Expression of COX-2 was determined by western blot and real time quantitative polymerase chain reaction (PCR). Expression profiles of cancer related genes were screened with cDNA array. In vivo growth of implanted MKN45 cells in nude mice was monitored after oral treatment with rosiglitazone.

Results: PPAR $\gamma$ ligands suppressed the in vitro growth of MKN45 cells in a dose dependent manner whereas prostacyclin, a PPARS agonist, had no growth inhibitory effect. Growth inhibition was more pronounced in MKN45 cells, which was accompanied by DNA fragmentation and downregulation of COX-2. Screening by CDNA microarray showed that PPAR ligand treatment was associated with upregulation of bad and p53, and downregulation of bcl-2, bcl-xl, and cyclin El in MKN45 cells, which was confirmed by quantitative real time PCR. In contrast, MKN28 cells with lower PPAR $\gamma$ and COX-2 expression levels had lower growth inhibitory responses to PPAR $\gamma$ ligands. Microarray experiments only showed induction of the bad gene in MKN28 cells. In vivo growth of MKN45 cells in nude mice was retarded by rosiglitazone. Mean tumour volume in rosiglitazone treated mice was significantly lower than controls at six weeks $(p=0.019)$ and seven weeks $(p=0.001)$ after treatment.

Conclusions: PPAR $\gamma$ ligands suppress both in vitro and in vivo growth of gastric cancer and may play a major role in cancer therapy and prevention.
\end{abstract}

Abbreviations: PPAR $\gamma$, peroxisome proliferator activated receptor $\gamma$; COX, cyclooxygenase; $\mathrm{PGJ}_{2}$, prostaglandin $\mathrm{J}_{2} ; \mathrm{PGI}_{2}$, carbaprostacyclin; FBS, fetal bovine serum; BrdU, bromodeoxyuridine; RT-PCR, reverse transcription-polymerase chain reaction 
have antitumorigenic effects on gastric cancer in vivo is unknown. In this study, we examined the in vitro and in vivo effects of PPAR $\gamma$ ligand activation on the growth of gastric cancer cells. Moreover, to elucidate the mechanisms underlying growth inhibition of PPAR $\gamma$ ligands, we determined expression of cyclooxygenase 2 (COX-2) and other tumour related genes in two gastric cell lines after treatment with PPAR $\gamma$ ligands.

\section{METHODS}

\section{Chemicals}

The PPAR $\gamma$ agonists ciglitazone and 15-deoxy- $\Delta^{12,14}$-prostaglandin $\mathrm{J}_{2}\left(\mathrm{PGJ}_{2}\right)$, the PPAR $\delta$ agonist carbaprostacyclin $\left(\mathrm{PGI}_{2}\right)$, and the COX-2 specific inhibitor NS398, were all obtained from Cayman Chemical (Ann Arbor, Michigan, USA). Rosiglitazone was kindly provided by Glaxo SmithKline (Hong Kong).

\section{Cell cultures}

The human gastric cancer cell lines MKN45 and MKN28 were obtained from Riken Gene Bank (Japan). They were cultured in RPMI medium 1640 (Invitrogen Co., Carlsbad, California, USA) with $10 \%$ fetal bovine serum (FBS) and $1 \%$ penicillinstreptomycin (Invitrogen Co.) at $37^{\circ} \mathrm{C}$ in a humidified atmosphere of $95 \%$ room air and $5 \% \mathrm{CO}_{2}$.

\section{Cell proliferation and apoptosis}

Cell proliferation was detected by a quantitative ELISA kit (Cell Proliferation ELISA; Roche, Germany) which measures bromodeoxyuridine (BrdU) incorporation during DNA synthesis. Cells were grown in 96 well culture dishes $\left(2 \times 10^{4}\right.$ cells/ well), incubated with PPAR ligands for 72 hours, and labelled with BrdU for another six hours. BrdU incorporation was measured colorimetrically.

Apoptosis was measured by the Cell Death Detection ELISA (Roche) which detects the amount of cytoplasmic histone associated DNA fragments. Similar to the proliferation assay, cells were grown in 96 well plates $\left(2 \times 10^{4}\right.$ cells/well $)$ with test agents for 72 hours. The amount of fragmented DNA was then measured colorimetrically, as suggested by the manufacturer.

\section{RNA extraction and cDNA synthesis}

Total RNA was extracted using RNA Trizol reagent (Invitrogen Co.). Total RNA ( $1 \mu \mathrm{g}$ ) was reverse transcribed into complementary DNA using dNTPs $(1 \mathrm{mM}), 5 \times$ reverse transcription buffer ( $500 \mathrm{mM}$ Tris $\mathrm{HCl}, \mathrm{pH} 8.3,250 \mathrm{mM} \mathrm{KCl}$, $50 \mathrm{mM} \mathrm{MgCl}_{2}$, and $50 \mathrm{mM}$ DTT), 16 units of RNasin ribonuclease inhibitor (Promega), and 2.5 units of AMV reverse transcriptase (GibcoBRL, Rockville, Maryland, USA).

\section{Real time quantitative reverse transcription- polymerase chain reaction (RT-PCR)}

Quantitation of PPAR $\gamma$ and COX-2 RNA expression was performed using the TaqMan real time PCR assay (ABI PRISM 7700 Sequence Detection System; PE Applied Biosystems, Foster City, California, USA), as described previously by Humar and colleagues. ${ }^{20}$ A gene specific PCR oligonucleotide primer pair and an oligonucleotide probe labelled with a reporter fluorescent dye at the $5^{\prime}$ end and a quencher fluorescent dye at the $3^{\prime}$ end were used. Sequences for primers and probes were:

- COX-2 forward primer 5'-GCCCTTCCTCCTGTGCC-3';

- COX-2 reverse primer 5' -AATCAGGAAGCTGCTTTTTAC-3'; and

- COX-2 probe 5'-ATGATTGCCCGACTCCCTTGGGTGT3';

- PPAR $\gamma$ forward primer 5'-GTCACGGAACACGTGCAGC-3';
- PPAR $\gamma$ reverse primer 5'-CAGGAGCGGGTGAAGACTCA-3'; and

- PPAR $\gamma$ probe 5'-ACTGCAGGTGATCAAGAAGACGGA GACAG-3';

- $\beta$-actin forward primer 5'-CTAATGGGCACCCAGCAC AATG-3';

- $\beta$-actin reverse primer 5'-GCCGATCCACACGGAGTACT-3'; and

- $\beta$-actin probe 5'-TCAAGATCATTGCTCCTCCTGAGCGC-3'.

Each amplification consisted of a $24 \mu \mathrm{l}$ reaction mix with $100 \mathrm{nM}$ of each probe, $300 \mathrm{nM}$ of each primer (or $25 \mathrm{~nm}$ of $\beta$-actin primer), $2.5 \mathrm{U}$ AmpliTaq gold polymerase, $200 \mu \mathrm{M}$ each of dATP, dCTP, and dGTP, $400 \mu \mathrm{M}$ dUTP, $5 \mathrm{mM} \mathrm{MgCl}_{2}$, 0.5 U AmpErase uracil N-glycosylase, and $1 \times$ Taqman buffer A (Roche Diagnostics). Complementary DNA (cDNA $1 \mu \mathrm{l}$ ) was added into each reaction. Reaction tubes were sealed with optical caps, and the PCR reaction was run on an ABI Prism 7700. Cycling conditions were $50^{\circ} \mathrm{C}$ for two minutes, $95^{\circ} \mathrm{C}$ for 10 minutes, followed by 40 cycles at $95^{\circ} \mathrm{C}$ for 20 seconds and $58^{\circ} \mathrm{C}$ for 45 seconds. Each sample was added in triplicate. A template free negative control was included in all amplifications. The intensity of the fluorescent dye was determined and expression of COX-2 was normalised to cDNA loading for each individual sample using $\beta$-actin as an internal standard. Changes in expression of COX-2 in treated cell lines were compared with vehicle treated cells.

\section{Western blot}

Total protein was extracted by Trizol (Invitrogen) and the concentration was determined by Lowry assay (Bio-Rad, Hercules, California, USA). Total protein $(25 \mu \mathrm{g})$ was resolved onto a $10 \%$ sodium dodecyl susphate-polyacrylamide gel. After electrophoresis, proteins were transferred to polyvinylidene difluoride blotting membranes (Amersham, Buckinghamshire, UK). Membranes were blocked in Tris buffered saline-T buffer with $10 \%$ skim milk at $4^{\circ} \mathrm{C}$, and incubated with primary antibody, goat polyclonal IgG antiCOX-2 (Santa Cruz Biotechnology, California, USA) at 1:1000 dilution. Membranes were then washed by Tris buffered saline-T buffer and incubated with corresponding secondary antibody. Enhanced chemiluminescence was detected by SuperSignal West Pico chemiluminescent substrate (Pierce, Rockford, Illinois, USA). Membranes were striped and reprobed with 1:2500 diluted mouse monoclonal anti- $\beta$-actin (Sigma-Aldrich, St Louis, Missouri, USA) as the expression control. Images were scanned by GS-700 Imaging Densitometer and analysed by Quantity One software version 4.2.1 (Bio-Rad). Expression of COX-2 protein in vehicle treated cells after standardisation with $\beta$-actin was compared with PPAR $\gamma$ ligand treated cells.

\section{cDNA microarray experiments}

Gene expression profiles of MKN28 and MKN45 gastric cell lines after treatment with PPAR $\gamma$ ligands were analysed by a commercially available gene expression array system (GEArray Q series Human Cancer Pathway Finder Gene Array; SuperArray, Bethesda, Maryland, USA). This array consists of 96 specific cDNA fragments of genes involved in apoptosis and cell senescence, cell cycle control and DNA damage repair, signal transduction molecules and transcription factors, angiogenesis, adhesion, invasion, and metastasis, as well as control sequences. We compared the expression profiles of these genes in vehicle control treated gastric cells and cells treated with $\mathrm{PGJ}_{2}(10 \mu \mathrm{M})$ or ciglitazone $(20 \mu \mathrm{M})$. Total RNA was isolated after 48 hours of treatment. Subsequent procedures were performed according to the manufacturer's suggestion. The arrays were visualised using a non-radioactive method and the intensity of the hybridisa- 
tion signals was quantitated by scanning densitometry after adjustment to housekeeping genes within the same array using the GE ArrayAnalyzer software (version 1.35; SuperArray Biosciences). Each experiment was performed in triplicate to ensure reproducibility of the results. Those genes with concordant twofold changes in expression levels by the two distinct PPAR $\gamma$ ligands, when compared with vehicle treated cells, were selected for examination by real time PCR.

Real time PCR was performed to confirm the results of the cDNA expression array experiments. The reaction was carried out in an ABI PRISM 7700 sequence detection system using SYBR green PCR reagents (Molecular Probes, Eugene, Oregon, USA). Detection of PCR products by agarose gel electrophoresis confirmed the homogeneity of the DNA products. Template free water was used as a negative control. Expression levels of target genes in PPAR $\gamma$ ligand treated cells were standardised against $\beta$-actin mRNA levels. Relative quantitation was expressed as fold induction or repression of the genes of interest compared with controls.

\section{In vivo tumour growth assay}

Eight week old male athymic nude mice (BALB/c nu/nu) were obtained from the Laboratory Animal Service Center of the Chinese University of Hong Kong. All mice were kept under specific pathogen free conditions using a laminar airflow rack and had free access to sterilised food and autoclaved water. All experiments were performed under license from the government of the Hong Kong SAR and endorsed by the Animal Experimentation Ethics Committee of the Chinese University of Hong Kong.

A MKN45 cell suspension $\left(5 \times 10^{4}\right.$ cells suspended in $0.1 \mathrm{ml}$ of media) was injected subcutaneously into the flank of each mouse on day 0 . Animals were randomly divided into two groups (eight animals per group): one group received rosiglitazone $(6 \mathrm{mg} / \mathrm{kg} / \mathrm{day})$ and the other received vehicle only. All study medications were given by oral gavage five times per week starting from day 1 of injection through to the end of week 7. Tumour size was measured weekly with callipers in three dimensions: that is, length (L), width (W), and height $(\mathrm{H})$. Tumour volume was calculated using the formula $(\pi \times \mathrm{L} \times \mathrm{W} \times \mathrm{H}) / 6{ }^{8}$ At the end of week 7 , all mice were sacrificed by cervical dislocation. Tumours were dissected from the body and fixed in buffered formalin for subsequent histological examination. Paraffin embedded tissues were deparaffined and stained with haematoxylin-eosin for histological examination. Proliferation of tumour cells was determined by Ki-67 immunostaining (Zymed, California, USA), as described previously. ${ }^{21}$ The proliferation index was expressed as the percentage of Ki-67 positive nuclei to total nuclei counted.

\section{Statistics}

Data are expressed as mean (SD). ANOVA with Bonferroni's multiple comparison correction was performed when more than two groups were compared. Differences in tumour volume between animals fed with rosiglitazone and vehicle controls were determined by the Student's $t$ test. A p value of $<0.05$ was considered statistically significant.

\section{RESULTS}

\section{PPAR $\gamma$ and COX-2 expression}

Both MNK28 and MKN45 cell lines expressed PPAR $\gamma$ and COX-2 by ordinary RT-PCR (fig 1). COX-2 expression was higher in MKN45 than in MKN28 cell lines whereas PPAR $\gamma$ expression levels appeared to be comparable. However, by quantitative PCR, expression levels of PPAR $\gamma$ and COX-2 were, respectively, 10-fold and 18-fold higher in MKN45 than in MKN28 cell lines.
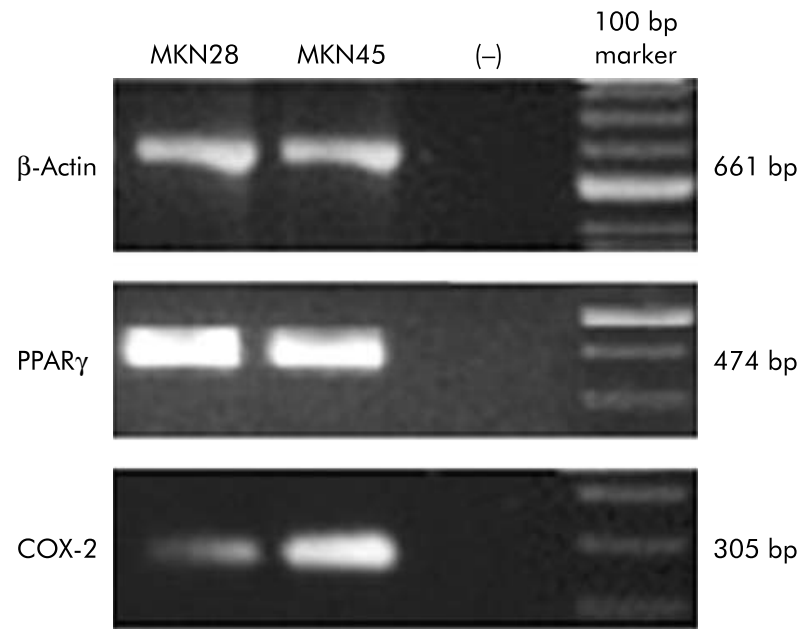

Figure 1 Expression of peroxisome proliferator activated receptor $\gamma$ (PPAR $\gamma$ ) and cyclooxygenase 2 (COX-2) in gastric cancer cells. mRNA expression levels of PPAR $\gamma$ and COX-2 in MKN28 and MKN45 gastric cancer cells. PPAR $\gamma$ was expressed in both cell lines whereas expression of COX-2 was higher in MKN45 than in MKN28 cell lines. The (-) lane indicates negative control (template free water).

\section{Effects of PPAR $\gamma$ ligands on proliferation of gastric cancer cell lines}

To determine the effect of PPAR $\gamma$ ligands on growth of gastric cells, both cell lines were treated with $\mathrm{PGJ}_{2}$ or ciglitazone in serum fast condition. As shown in fig $2 \mathrm{~A}$ and $2 \mathrm{~B}$, treatment with $\mathrm{PGJ}_{2}$ and ciglitazone suppressed the growth of MKN45 cells in a dose dependent manner. Time dependent growth suppression was noted (data not shown) and maximal effects were detected at 72 hours. At this time point, there was approximately $80 \%$ growth inhibition with $10 \mu \mathrm{M} \mathrm{PGJ}_{2}$ $(\mathrm{p}<0.05 v$ control $)$ and $50 \mu \mathrm{M}$ ciglitazone $(\mathrm{p}<0.01 v$ control $)$. In contrast, the growth inhibitory effect of PPAR $\gamma$ ligands was less prominent in MKN28 cells (fig 2C, 2D). There was approximately $60 \%$ reduction in proliferation with $10 \mu \mathrm{M}$ $\mathrm{PGJ}_{2}(\mathrm{p}<0.01 v$ control) but treatment with ciglitazone was not associated with any growth suppressive effect. Notably, addition of $10 \%$ FBS in the culture medium ameliorated the growth inhibitory effect of $\mathrm{PGJ}_{2}$ and ciglitazone. After addition of FBS, there was only approximately $40 \%$ growth inhibition with $\mathrm{PGJ}_{2}(10 \mu \mathrm{M})$ and $20 \%$ inhibition with ciglitazone $(20 \mu \mathrm{M})$. In contrast, treatment with $\mathrm{PGI}_{2}$, the PPAR $\delta$ agonist, has no effect on proliferation of MKN28 and MKN45 cells, either in the presence or absence of FBS.

\section{Induction of apoptosis by PPAR $\gamma$ ligands}

After treatment with $\mathrm{PGJ}_{2}$ or ciglitazone in MKN45 cells, there was an increase in the amount of fragmented DNA in the cytoplasm, as detected by ELISA (fig 3). There was approximately 1.5 -fold and 4.6-fold increase in DNA fragmentation after 72 hours of treatment with PGJ $(10 \mu \mathrm{M})$ and ciglitazone $(20 \mu \mathrm{M})$, respectively.

\section{PPAR $\gamma$ ligand activation and COX-2 expression}

Treatment with $\mathrm{PGJ}_{2} 1 \mu \mathrm{M}$ and $10 \mu \mathrm{M}$ for 72 hours resulted in $54 \%(\mathrm{p}<0.05 v$ control $)$ and $66 \%(\mathrm{p}<0.01 \quad v$ control $)$ reduction in COX-2 protein expression (fig $4 \mathrm{~A}$ ). Moreover, there was a $46 \%(\mathrm{p}<0.05 v$ control $)$ and $67 \%(\mathrm{p}<0.01 v$ control) reduction in COX-2 protein expression after treatment with ciglitazone $3 \mu \mathrm{M}$ and $10 \mu \mathrm{M}$, respectively. A dose dependent reduction in COX-2 mRNA level after treatment with $\mathrm{PGJ}_{2}$ was also shown by real time quantitative PCR $(p=0.041$; fig 4B). However, treatment with PPAR $\gamma$ ligands 

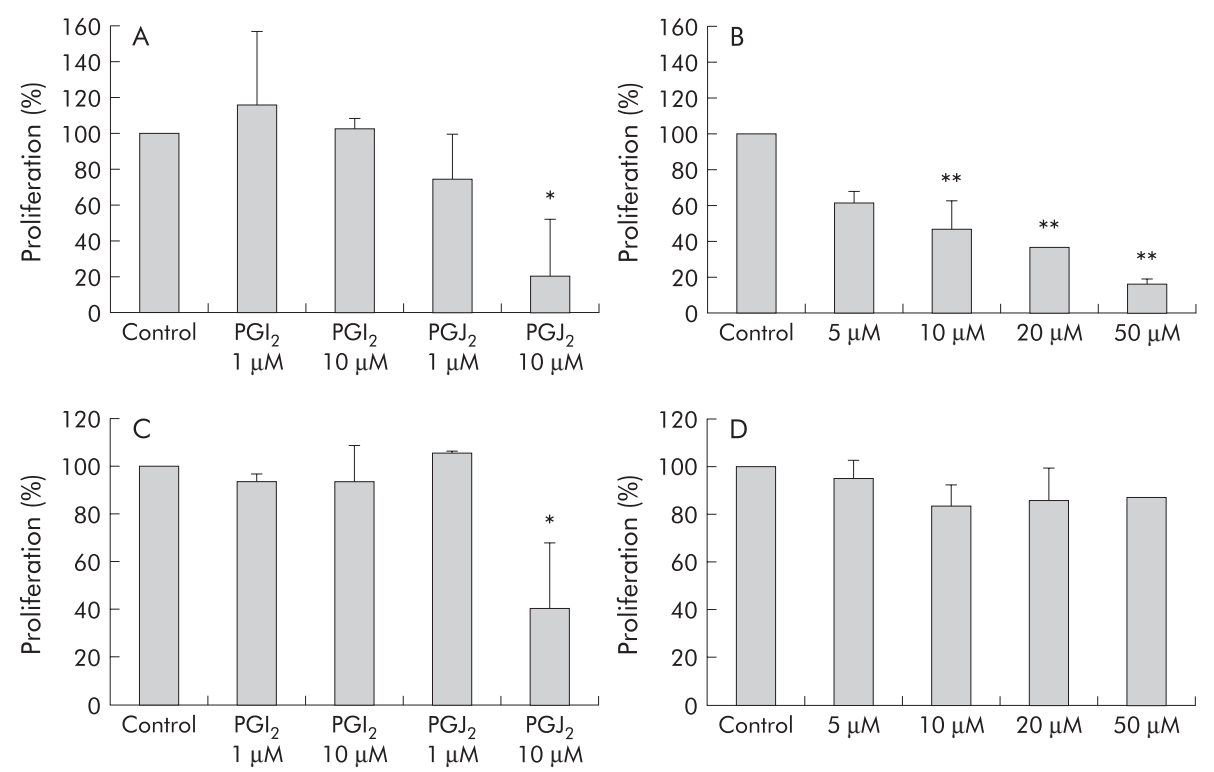

Figure 2 Effect of peroxisome proliferator activated receptor (PPAR) ligands on proliferation of MKN45 (A, B) and MKN28 (C, D) cells. Cell lines were treated with various doses of the PPAR $\delta$ agonist (carbaprostacyclin $\left(\mathrm{PGI}_{2}\right) 1$ and $10 \mu \mathrm{M}$ ) and PPAR $\gamma$ agonists (prostaglandin $J_{2}\left(P G J_{2}\right) 1$ and $10 \mu M$ or ciglitazone 5-50 $\mu \mathrm{M}$ (B, D)). Cell proliferation was determined by bromodeoxyuridine incorporation in serum free condition. The y axis indicates the percentage of proliferation compared with controls (100\%). (A) Treatment with PGJ $\mathrm{J}_{2}(10 \mu \mathrm{M})$ in serum free condition was associated with $80 \%$ growth suppression ( ${ }^{*} \mathrm{p}<0.05 \mathrm{v}$ control) in MKN45 cells but there was negligible growth inhibitory effects with $\mathrm{PGI}_{2}$ treatment. (B) Treatment with ciglitazone at doses $>10 \mu \mathrm{M}$ were associated with marked growth inhibition on MKN45 cells (** $\mathrm{p}<0.01 v$ control). (C) Treatment with different doses of PGI 2 (1 and $10 \mu \mathrm{M}$ ) or low dose PGJ $\mathrm{P}_{2}(1 \mu \mathrm{M})$ had no suppressive effect on MKN28 cells, except when $\mathrm{PGJ}_{2} 10 \mu \mathrm{M}$ was used (* $<<0.05 v$ control). (D) Treatment with different doses of ciglitazone (5-50 $\mu \mathrm{M})$ was not associated with any growth inhibitory effects on MKN28 cells.

had no effect on COX-2 expression on MKN28 cells (data not shown).

Although the use of NS398 $(100 \mu \mathrm{M})$ or PPAR $\gamma$ ligands ( $10 \mu \mathrm{M} \mathrm{PGJ}_{2}$ and $20 \mu \mathrm{M}$ ciglitazone) alone suppressed growth of MKN45 cells, the combined use of these two
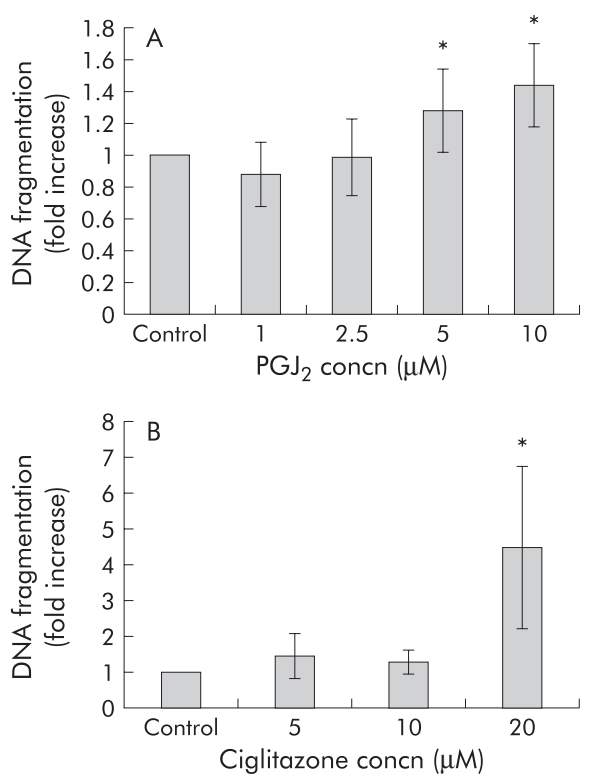

Figure 3 Induction of apoptosis by peroxisome proliferator activated receptor $\gamma$ (PPAR $\gamma$ ) ligands. Treatment with PPAR $\gamma$ ligands was associated with an increase in the amount of DNA fragmentation. (A) Treatment with prostaglandin $\mathrm{J}_{2}\left(\mathrm{PGJ} \mathrm{J}_{2}\right)$ at doses $>5 \mu \mathrm{M}$ was associated with an increase in DNA fragmentation ( ${ }^{*} p<0.05 v$ control). (B) A similar increase in DNA fragmentation was observed with high dose ciglitazone treatment $\left(20 \mu \mathrm{M},{ }^{*} \mathrm{p}<0.05 v\right.$ control). agents did not have any synergistic effect on growth suppression (fig 5).

\section{Gene expression profiles}

Screening by cDNA microarray showed that there was concordant upregulation of bad and downregulation of $b c l-2$ and $b c l-x l$ in MKN45 cells after treatment with the two PPAR $\gamma$ ligands (ciglitazone and $\mathrm{PGJ}_{2}$ ). In addition, there was repression of cyclin E1 and activation of $p 53$ in MKN45 cells after treatment. Quantitative PCR confirmed that treatment with PPAR $\gamma$ ligands was associated with upregulation of bad $(\mathrm{p}<0.01 v$ control $)$ and $p 53(\mathrm{p}<0.01 v$ control $)$ whereas expression of $b c l-x l \quad(\mathrm{p}<0.01 \vee$ control $), b c l-2 \quad(\mathrm{p}<0.01 \quad v$ control), and cyclin El $(\mathrm{p}<0.05 v$ control) was suppressed in treated cells (fig 6). In contrast, only the bad gene was induced by the two PPAR $\gamma$ ligands whereas expression of the other four genes remained unchanged in MKN28 cells. Furthermore, not all genes showed concordant alteration by the two PPAR $\gamma$ ligands. The following genes were only repressed by ciglitazone but not by $\mathrm{PGJ}_{2}$ in MKN45 cells: angiopoietin 2, epidermal growth factor, vascular endothelial growth factor receptor, and integrin alpha-1, alpha-4, and beta-3. On the other hand, $\mathrm{PGJ}_{2}$, but not ciglitazone, appeared to suppress tumour necrosis factor $\alpha$ and induce pl6 expression in MKN45 cells.

\section{Effect of PPAR $\gamma$ ligand on tumour growth in vivo}

Subcutaneous tumour growth was first palpable four weeks after injection of MKN45 cells (fig 7A). At week 6, there was a significant difference in tumour volume between rosiglitazone treated mice and control mice $\left(48.8(54.9) \mathrm{mm}^{3} v 166.3\right.$ (73.3) $\mathrm{mm}^{3} ; \mathrm{p}=0.019$ ) (fig 7D). At week 7, there was mild shrinkage of tumour volume in rosiglitazone treated group whereas tumours continued to grow in the vehicle control group. Hence the difference between the two groups was more pronounced at week $7 \quad\left(33.9 \quad(33.7) \mathrm{mm}^{3} v 226.2\right.$ (107.4) $\mathrm{mm}^{3} ; \mathrm{p}=0.001$ ). Body weight in the two treatment 

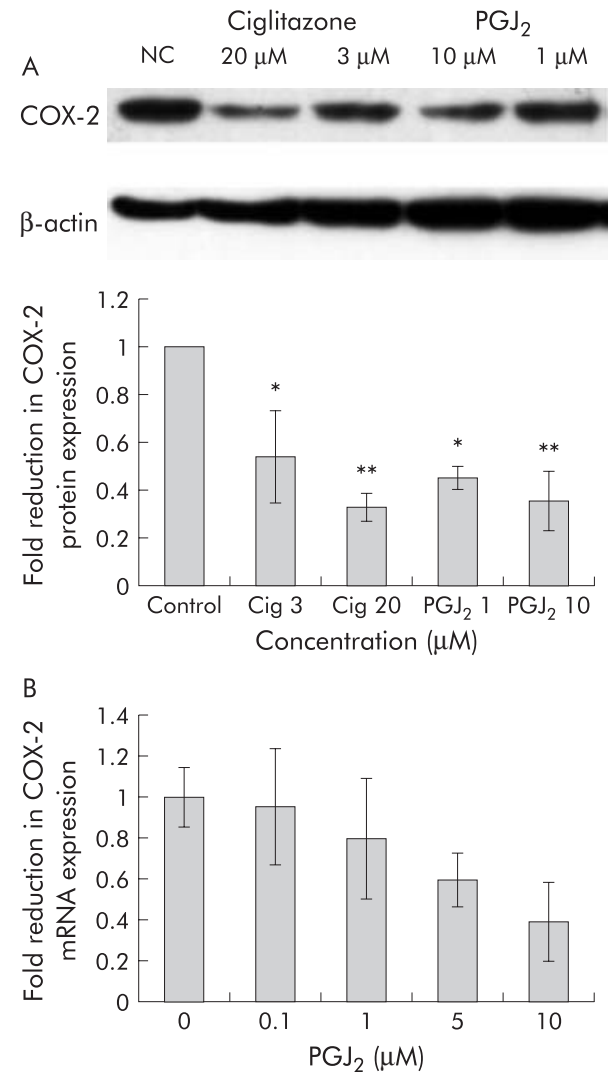

Figure 4 Treatment with peroxisome proliferator activated receptor $\gamma$ (PPAR $\gamma$ ) ligands downregulates cyclooxygenase 2 (COX-2) expression. Treatment with PPAR $\gamma$ ligands was associated with downregulation of COX-2 mRNA and protein expression. (A) There was more than $40 \%$ reduction in COX-2 protein expression with ciglitazone (Cig) at doses $>3 \mu \mathrm{M}\left(\mathrm{p}<0.05 v\right.$ control) and prostaglandin $\mathrm{J}_{2}\left(\mathrm{PGJ}_{2}\right)$ at doses $>1 \mu \mathrm{M}$ $\left(p<0.05 v\right.$ control). ${ }^{*} p<0.05,{ }^{* *} p<0.01$ versus controls; $p=008$, ANOVA. (B) Treatment with $P G J_{2}$ resulted in a dose dependent reduction in COX-2 mRNA expression, as detected by quantitative polymerase chain reaction ( $p=0.041$, ANOVA).

groups was comparable and none of the study animals died during the study period. Histological examination of the tumour confirmed the presence of cancer cells within the tumour and there was no apparent difference in the morphology of tumour cells between the two groups (fig 7B, 7C). The proliferation index of the tumour tended to be lower in animals treated with rosiglitazone than in controls $(0.48$ $(0.07) \%$ \% $0.57(0.09) \% ; \mathrm{p}=0.16)$.

\section{DISCUSSION}

In this study we have demonstrated both the in vivo and in vitro growth suppressive effects of PPAR $\gamma$ ligands on gastric cancer cells. The in vitro antiproliferative effect of PPAR $\gamma$ ligands was dose dependent and was more prominent in MKN45 cells. Treatment with a PPAR $\delta$ agonist, carbaprostacyclin, had no effect on the growth of gastric cells. This is in agreement with a recent report by Kojima et al which also failed to show any effect of PPAR $\delta$ agonists on the growth of gastric cells. ${ }^{19}$ The presence of serum however ameliorated the growth suppressive effect of the two PPAR $\gamma$ ligands. This antagonistic effect of serum is attributed to the presence of polypeptide growth factors and other cell protective substances in serum. ${ }^{22} 23$

Despite the promising in vitro data, the in vivo antitumorigenic effect of PPAR $\gamma$ ligands is controversial. ${ }^{4} 5^{14}{ }^{15}$ In this study, we demonstrated a significant reduction in the in vivo
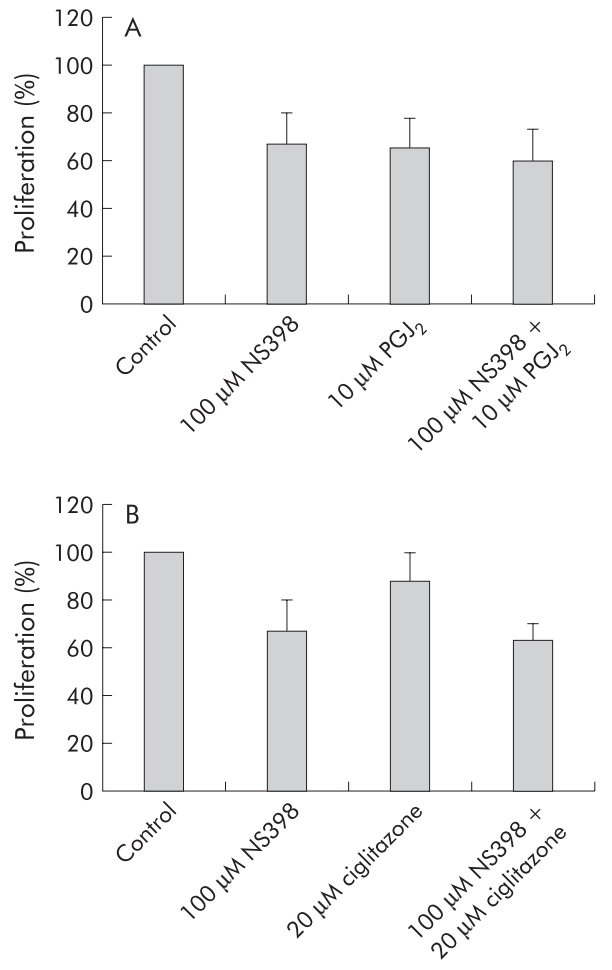

Figure 5 Combined treatments of peroxisome proliferator activated receptor $\gamma$ (PPAR $\gamma$ ) ligands and cyclooxygenase 2 (COX-2) inhibitors on growth of gastric cells. (A) MKN45 cells were treated with the COX-2 inhibitors NS398 $(100 \mu \mathrm{M})$ and prostaglandin $J_{2}\left(\mathrm{PGJ}_{2} 10 \mu \mathrm{M}\right)$, alone or in combination. Both NS398 and PGJ 2 alone suppressed the growth of MKN45 gastric cells but the combined use of these two agents did not have any synergistic effect on growth. (B) Similarly, there was no additional growth suppression with the combined use of NS398

$(100 \mu \mathrm{M})$ and ciglitazone $(20 \mu \mathrm{M})$. All experiments were performed in the presence of $10 \%$ fetal bovine serum and thus the growth suppressive effects of $\mathrm{PGJ}_{2}$ and ciglitazone were lower than in serum fast conditions, as shown in fig 2 .

growth of MKN45 cells in nude mice after treatment with rosiglitazone. At a modest dose of rosiglitazone $(6 \mathrm{mg} / \mathrm{kg} /$ day) there was a significant reduction in tumour volume compared with those treated with vehicle alone. While tumour development was noticed four weeks after implantation, there was a significant difference in tumour size from six weeks onwards (fig 7). Notably, the dose of rosiglitazone used in our study was much lower than in a recent in vivo study that examined the antiangiogenic effect of PPAR $\gamma$ ligands. ${ }^{11}$ Panigrahy et al showed that neovascularisation and tumour metastasis were suppressed by rosiglitazone $50-100 \mathrm{mg} / \mathrm{kg} / \mathrm{day}$. This discrepancy may be related to the differential antiproliferative responses of different tissue types to PPAR $\gamma$ ligands. In keeping with this speculation, some cancer cells such as bladder, breast, and thyroid may require higher doses of PPAR $\gamma$ ligands for growth inhibition in vitro. ${ }^{7} 102425$

In MKN45 gastric cells, the growth suppressive effect of high dose $\mathrm{PGJ}_{2}(10 \mu \mathrm{M})$ and ciglitazone $(20 \mu \mathrm{M})$ was accompanied by apoptosis induction with a modest increase in DNA fragmentation. Additionally, we determined expression of COX-2, which has been shown to inhibit apoptosis in transformed cells, after PPAR $\gamma$ ligand treatment. ${ }^{26}$ Our results showed that there was a dose dependent reduction in COX-2 mRNA and protein expression after treatment with PPAR $\gamma$ ligands. There was approximately 50\% reduction in COX-2 expression with $\mathrm{PGJ}_{2}(10 \mu \mathrm{M})$ or ciglitazone $(10 \mu \mathrm{M})$ treatment. In keeping with this, downregulation of COX-2 

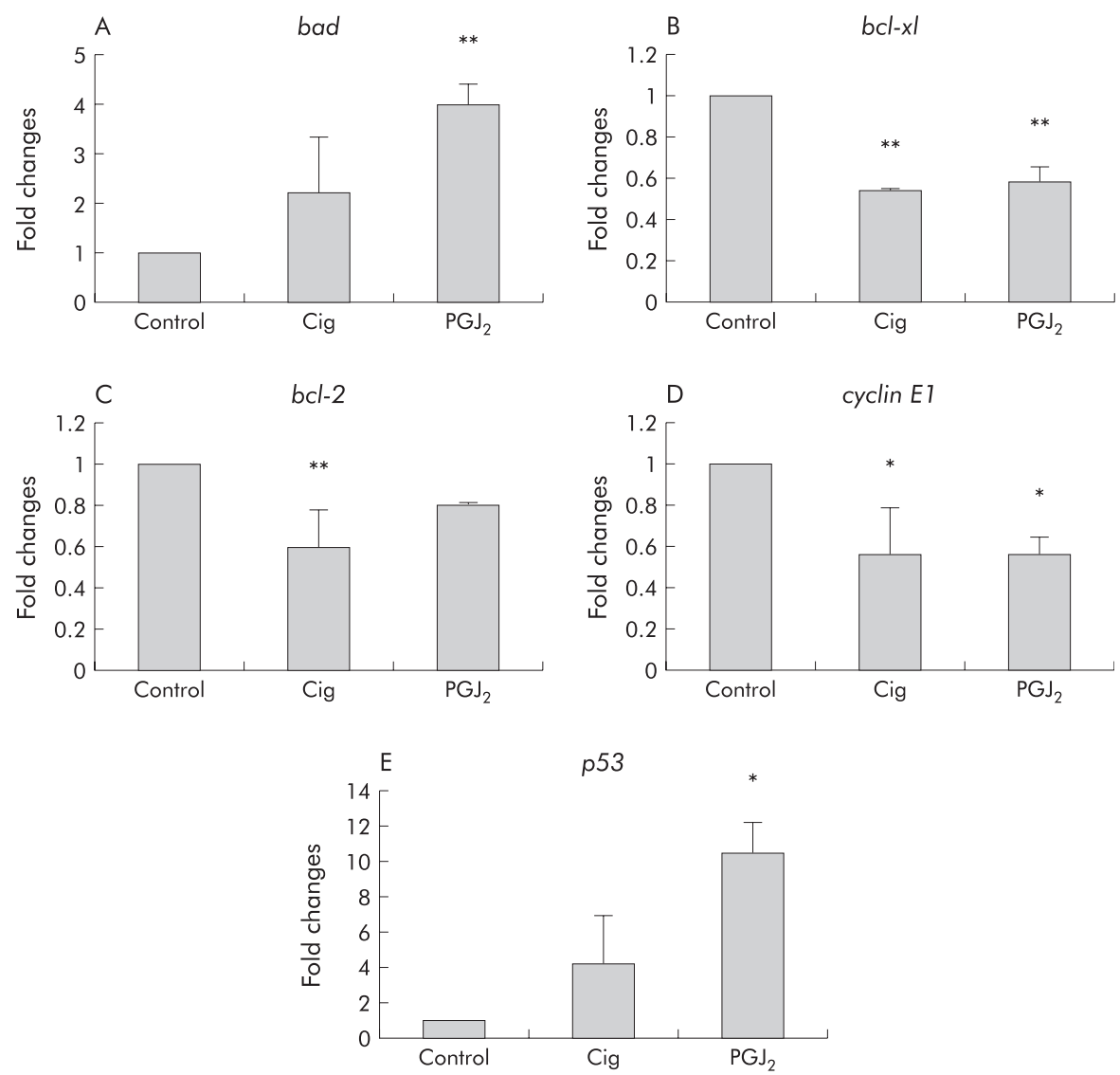

Figure 6 Quantitative polymerase chain reaction (PCR) in the determination of expression levels of selected genes in MKN45 cells. Genes with altered expression, as detected by cDNA microarray, were selected for examination by quantitative PCR. mRNA expression levels of (A) bad, (B) bcl-xl, (C) bcl-2, (D) cyclin $E I$, and (E) p53 after treatment with prostaglandin $J_{2}\left(P G J_{2} 10 \mu M\right)$ or ciglitazone (Cig $\left.20 \mu M\right)$ were determined. Results are shown as mean (SD) after standardisation to $\beta$-actin in three separate experiments. ${ }^{*} \mathrm{p}<0.05,{ }^{* *} \mathrm{p}<0.01$ versus controls.

has also been demonstrated in colonic cells after treatment with ciglitazone. ${ }^{27} \mathrm{~A}$ recent study on a mammary cell line suggested that PPAR $\gamma$ ligands inhibit activator protein 1 mediated transcriptional activation of COX $-2 .{ }^{28}$ Although the use of PPAR $\gamma$ ligands or a specific COX-2 inhibitor (NS398) alone inhibits gastric cancer cell growth, the combined use of these two agents had no additional or synergistic effect on growth. Intuitively, this finding may suggest that COX-2 inhibitors and PPAR $\gamma$ ligands act through a common pathway on growth suppression.

In addition to differences in COX-2 expression, there are other possible explanations to account for the differential responses of the two cell lines to PPAR $\gamma$ ligands. Firstly, MNK45 cells have higher PPAR $\gamma$ expression, as demonstrated by quantitative PCR. Secondly, recent data showed that mice with pre-existing damage to the $A p c$ gene developed colon tumours in a manner insensitive to the status of PPAR $\gamma,{ }^{29}$ suggesting that PPAR $\gamma$ suppress $\beta$-catenin levels and colon carcinogenesis only before damage to the APC/ $\beta$-catenin pathway. In this regard, the MKN28 cell line, which has a mutation in the $A p c$ gene, ${ }^{30}$ may have a reduced response to ciglitazone and $\mathrm{PGJ}_{2}$. Intriguingly, although PPAR $\gamma$ ligands have been shown to induce apoptosis in a number of gastric cell lines, activation of the PPAR $\gamma$ pathway attenuates the ability of Helicobacter pylori to induce nuclear factor $\mathrm{\kappa B}$ mediated apoptosis in gastric epithelial cells. ${ }^{31}$ Hence activation of the PPAR $\gamma$ receptor may result in varying levels of cellular turnover depending on the intrinsic properties of the cells.
By screening the expression profiles of cancer related genes after treatment with PPAR $\gamma$ ligands, we demonstrated upregulation of bad and $p 53$ and downregulation of $b c l-x l$, $b c l-2$, and cyclin El in MKN45 cells. Both $b c l-2$ and $b c l-x l$ have an antiapoptotic function by preventing cytochrome c release and hence caspase-9 activation. In line with this finding, there was induction of bad, a proapoptotic gene, by PPAR $\gamma$ ligands. A similar finding was demonstrated in breast cancer cells in which treatment with PPAR $\gamma$ ligands was associated with downregulation of $b c l-2 .^{7}$ Cyclin El is responsible for $\mathrm{Gl} / \mathrm{S}$ progression in mammalian cells and overexpression is implicated for neoplasia, including gastric cancer. ${ }^{32}{ }^{33}$ To this end, downregulation of cyclin El by PPAR $\gamma$ ligands may offer another explanation for the growth inhibition in gastric cancer cells. Previous studies on other cell types have demonstrated that treatment with PPAR $\gamma$ ligands is associated with reduced cyclin DI expression and upregulation of cyclin dependent kinase inhibitors p $18^{\text {INK4C }}$ and p $21^{\text {Wafl/Cipl }} .^{34-36}$ However, there was no obvious alteration in cyclin D1 or $p 21$ expression in MKN45 cells. In contrast, we demonstrated activation of $p 53$ by PPAR $\gamma$ ligands in MKN45 cells with wild type $p 53 .^{30}$ Similar activation of $p 53$ was demonstrated in vascular smooth muscle cells after treatment with troglitazone. ${ }^{37}$ By comparing the gene expression profiles of the two gastric cell lines, we found that the bad gene was the only gene altered by the two PPAR $\gamma$ ligands in MKN28 cells. This finding may further explain the reduced growth inhibitory response of this cell line to PPAR $\gamma$ ligand activation. Interestingly, a recent report on colonic cells showed that 

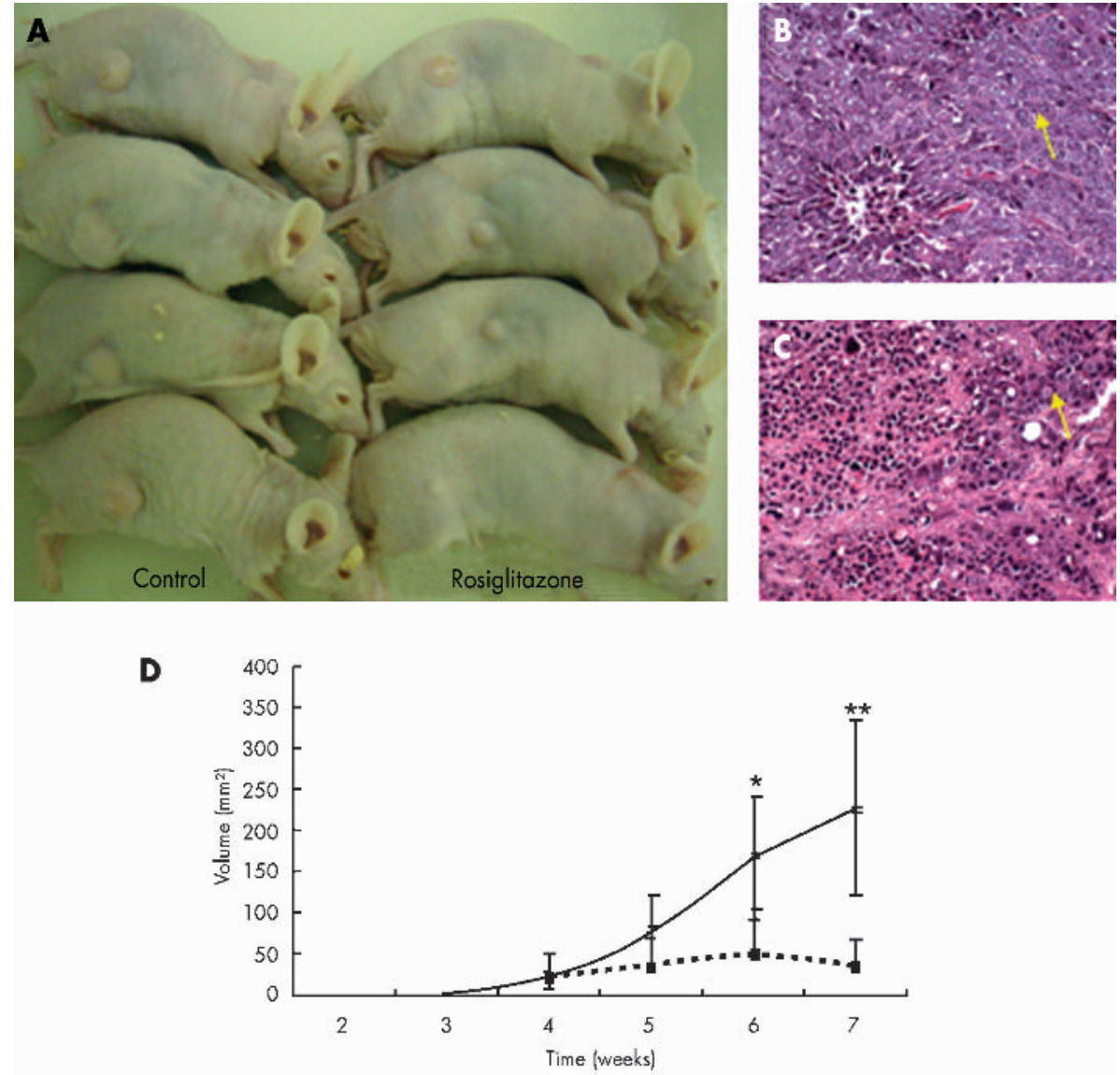

Figure 7 In vivo growth of MKN45 cells in nude mice. (A) Representative tumour growth in nude mice fed with vehicle control (left) and rosiglitazone (right). ( $B, C$ ) Haematoxylin-eosin sections of MKN45 tumours from the control group (B) and rosiglitazone group (C), with yellow arrows showing sheets of gastric cancer cells. There was no obvious difference in the degree of tumour differentiation and necrosis between the two groups. (D) The tumour growth rate was significantly lower in the rosiglitazone treated group compared with controls at week $6\left({ }^{*} p=0.02\right)$ and week $7\left({ }^{* *} p=0.0014\right)$. The solid line represents control mice whereas the broken line represents rosiglitazone treated mice.

treatment with PPAR $\gamma$ ligands was associated with downregulation of c-myc and upregulation of c-jun and gadd 153 in colonic cells. ${ }^{22}$ Thus the investigators speculated that PPAR $\gamma$ ligands compensate for dysregulated c-myc expression caused by a mutated $A p c$ gene in colon cancer cells. However, our array experiments failed to show alterations in these loci in MKN45 gastric cells after treatment with PPAR $\gamma$ ligands, which may be related to the presence of the wild-type $A p c$ gene in this cell line. ${ }^{30}$

In conclusion, PPAR $\gamma$ ligands inhibit the growth of gastric cancer both in vitro and in vivo. The antineoplastic effects are mediated by multiple pathways, including suppression of COX-2, inhibition of the antiapoptotic $b c l-2 / b c l-x l$ family and cyclin E1, and activation of $p 53$. While we and others have previously demonstrated the ubiquitous expression of PPAR $\gamma$ in primary gastric cancer tissues, ${ }^{18} 38$ the role of PPAR $\gamma$ ligands in the chemoprevention and therapy of human gastric cancer warrants further evaluation.

\section{ACKNOWLEDGEMENTS}

This study was supported by the Shanghai-Hong Kong-Anson Research Foundation for CAS and CUHK in Molecular Biosciences (SHARF) and the Direct Grant for Research of the Chinese University of Hong Kong. We would like to thank Po-Ki Ma and Minnie Go for their technical assistance.

\section{Authors' affiliations}

W K Leung, A H C Bai, V Y W Chan, J Yu, M W Y Chan, K-K Chan, Y-G Fu, F K L Chan, J J Y Sung, Department of Medicine and Therapeutics, The Chinese University of Hong Kong, Prince of Wales Hospital, Shatin, Hong Kong

K-F To, Department of Anatomical and Cellular Pathology, The Chinese University of Hong Kong, Prince of Wales Hospital, Shatin, Hong Kong J-R Wu, Laboratory of Molecular Cell Biology, Institute of Biochemistry and Cell Biology, Shanghai Institutes for Biological Sciences, Chinese Academy of Sciences, Shanghai, China

\section{REFERENCES}

1 Tontonoz P, Hu E, Spiegelman BM. Stimulation of adipogenesis in fibroblasts by PPAR gamma 2, a lipid-activated transcription factor. Cell 1994;79:1147-56.

2 Auwerx J. Nuclear receptors. I. PPAR gamma in the gastrointestinal tract: gain or pain, Am J Physiol Gastrointest Liver Physiol 2002;282:G581-5.

3 DuBois RN, Gupta R, Brockman J, et al. The nuclear eicosanoid receptor, PPARgamma, is aberrantly expressed in colonic cancers. Carcinogenesis 1998;19:49-53.

4 Brockman JA, Gupta RA, Dubois RN. Activation of PPARgamma leads to inhibition of anchorage-independent growth of human colorectal cancer cells. Gastroenterology 1998;115:1049-55.

5 Sarraf $P$, Mueller E, Jones D, et al. Differentiation and reversal of malignant changes in colon cancer through PPARgamma. Nat Med 1998:4:1046-52.

6 Kopelovich L, Fay JR, Glazer RI, et al. Peroxisome proliferator-activated receptor modulators as potential chemopreventive agents. Mol Cancer Ther 2002;1:357-63.

7 Elstner E, Muller C, Koshizuka K, et al. Ligands for peroxisome proliferatoractivated receptor and retinoic acid receptor inhibit growth and induce 
apoptosis of human breast cancer cells in vitro and in BNX mice. Proc Natl Acad Sci U S A 1998;95:8806-11.

8 Itami A, Watanabe G, Shimada Y, et al. Ligands for peroxisome proliferatorsactivated receptor $\gamma$ inhibit growth of pancreatic cancers both in vitro and in vivo. Int J Cancer 2001:94:370-6.

9 Kubota T, Koshizuka K, Williamson EA, et al. Ligand for peroxisome proliferator-activated receptor (troglitazone) has potent antitumor effect against human prostatic cancer both in vitro and in vivo. Cancer Res 1998:58:3344-52

10 Mueller E, Sarraf $P$, Tontonoz $P$, et al. Terminal differentiation of human breast cancer through PPAR $\gamma$. Mol Cell 1998;1:465-70

11 Panigrahy $D$, Singer S, Shen $L Q$, et al. PPAR $\gamma$ ligands inhibit primary tumor growth and metastasis by inhibiting angiogenesis. J Clin Invest 2002; 110:923-32.

12 Osawa E, Nakajima A, Wada K, et al. Peroxisome proliferator-activated receptor gamma ligands suppress colon carcinogenesis induced by azoxymethane in mice. Gastroenterology 2003;124:361-7.

13 Tanaka T, Kohno H, Yoshitani S, et al. Ligands for peroxisome proliferator activated receptors alpha and gamma inhibit chemically induced colitis and formation of aberrant crypt foci in rats. Cancer Res 2001;61:2424-8.

14 Lefebvre AM, Chen I, Desreumaux $P$, et al. Activation of the peroxisome proliferator-activated receptor gamma promotes the development of colon tumors in C57BL/6J-APCMin/+mice. Nat Med 1998;4:1053-7.

15 Saez E, Tontonoz P, Nelson MC, et al. Activators of the nuclear receptor PPARgamma enhance colon polyp formation. Nat Med 1998;4:1058-61.

16 Pisani P, Parkin DM, Bray F, et al. Estimates of the worldwide mortality from 25 cancers in 1990. Int $J$ Cancer 1999;83:18-29.

17 Takahashi N, Okumura T, Motomura W, et al. Activation of PPAR $\gamma$ inhibits cell growth and induces apoptosis in human gastric cancer cells. FEBS Lett 1999;455:135-9.

18 Sato H, Ishihara S, Kawashima K, et al. Expression of peroxisome proliferator-activated receptor (PPAR)gamma in gastric cancer and inhibitory effects of PPARgamma agonists. Br J Cancer 2000;83:1394-400.

19 Kojima K, Shimada T, Mitobe Y, et al. Effect of PPAR $\gamma$ ligands on the viability of gastric epithelial cells. Aliment Pharmacol Ther 2002; 16(suppl 2):67-73.

20 Humar B, Giovanoli O, Wolf A, et al. Germline alterations in the cyclooxygenase-2 gene are not associated with the development of extracolonic manifestations in a large Swiss familial adenomatous polyposis kindred. Int J Cancer 2000;87:812-17.

21 Yu J, Leung WK, Go MY, et al. Relationship between Helicobacter pylori babA2 status with gastric epithelial cell turnover and premalignant gastric lesions. Gut 2002;51:480-4.

22 Shimada T, Kojima K, Yoshiura K, et al. Characteristics of the peroxisome proliferators activated receptor $\gamma$ (PPAR $\gamma$ ) ligand induced apoptosis in colon cancer cells. Gut 2002;50:658-64.
23 Bishop-Bailey D Hla T. Endothelial cell apoptosis induced by the peroxisome proliferator-activated receptor (PPAR) ligand 15-deoxy-Delta12, 14 prostaglandin J2. J Biol Chem 1999;274:17042-8.

24 Nakashiro K, Hayashi Y, Kita A, et al. Role of peroxisome proliferatoractivated receptor and its ligands in non-neoplastic and neoplastic human urothelial cells. Am J Pathol 2001;159:591-7.

25 Ohta K, Endo T, Haraguchi K, et al. Ligands for peroxisome proliferatoractivated receptor inhibit growth and induce apoptosis of human papillary thyroid carcinoma cells. J Clin Endocrinol Metab 2001;86:2170-7.

26 Tsujii M, Dubois RN. Alterations in cellular adhesion and apoptosis in epithelial cells overexpressing prostaglandin endoperoxide synthase 2. Cell 1995;83:493-501.

27 Yang W, Frucht $\mathrm{H}$. Activation of the PPAR pathway induced apoptosis and COX-2 inhibition in HT-29 human colon cancer cells. Carcinogenesis 2001;22:1379-83.

28 Subbaramaiah K, Lin DT, Hart JC, et al. Peroxisome proliferator-activated receptor $\gamma$ ligands suppress the transcriptional activation of cyclooxygenase-2. J Biol Chem 2001;276:12440-8.

29 Girnun GD, Smith WM, Drori S, et al. APC-dependent suppression of colon carcinogenesis by PPARgamma. Proc Natl Acad Sci U S A 2002;99:13771-6

30 Yokozaki H. Molecular characteristics of eight gastric cancer cell lines established in Japan. Pathol Int 2000;50:767-77.

31 Gupta RA, Polk DB, Krishna U, et al. Activation of peroxisome proliferatoractivated receptor gamma suppresses nuclear factor kappa B-mediated apoptosis induced by Helicobacter pylori in gastric epithelial cells. J Biol Chem 2001;276:31059-66.

32 Sakaguchi T, Watanabe A, Sawada H, et al. Prognostic value of cyclin E and p53 expression in gastric carcinoma. Cancer 1998;82:1238-43.

33 Takano Y, Kato Y, van Diest PJ, et al. I Cyclin D2 overexpression and lack of p27 correlate positively and cyclin E inversely with a poor prognosis in gastric cancer cases. Am J Pathol 2000;156:585-94.

34 Chang TH, Szabo E. Induction of differentiation and apoptosis by ligands of peroxisome proliferator-activated receptor gamma in non-small cell lung cancer. Cancer Res 2000;60:1129-38.

35 Morrison RF, Farmer SR. Role of PPARgamma in regulating a cascade expression of cyclin-dependent kinase inhibitors, p18(INK4c) and p21(Wafl/ Cip1), during adipogenesis. J Biol Chem 1999;274:17088-97.

36 Wang C, Fu M, D'Amico $M$, et al. Inhibition of cellular proliferation through lkappaB kinase-independent and peroxisome proliferator-activated receptor gamma-dependent repression of cyclin D1. Mol Cell Biol 2001;21:3057-70.

37 Okura T, Nakamura M, Takata Y, et al. Troglitazone induces apoptosis via the p53 and Gadd45 pathway in vascular smooth muscle cells. Eur J Pharmacol 2000;407:227-35.

38 Leung WK, Yu J, Cheng ASL, et al. Constitutive expression of peroxisome proliferator-activated receptor (PPAR) $\delta$ and $\gamma$ in gastric carcinomas and nonneoplastic gastric mucosa. Gastroenterology 2001;120:A495.

\section{GI SNAPSHOT}

Answer

From question on page 330

These histological findings are characteristic of Menetrier's disease; a rare and acquired disorder of the stomach. Criteria for diagnosis include giant gastric folds, histological features of marked foveolar hyperplasia, atrophy of glands, and increase in mucosal thickness. There is excess mucus production, decreased acid secretion, and hypoproteinaemia. The differential diagnosis includes Zollinger-Ellison syndrome, Helicobacter pylori infection, gastric lymphoma, cytomegalovirus infection, gastric cancer, and eosinophilic gastritis. The pathogenesis involves elevated levels of transforming growth factor $\alpha$ (TGF- $\alpha$ ) in gastric mucous cells, which exerts its effect by binding to the epidermal growth factor receptor. TGF- $\alpha$ increases gastric mucous production, cell renewal, and inhibits acid secretion. Hypoproteinaemia occurs due to selective loss of serum proteins across the gastric mucosa. The patient underwent total gastrectomy due to ongoing blood loss that was difficult to manage, with iron and blood supplementation without complications. The patient continues to do well one year after surgery with no anaemia, gastrointestinal bleeding, or abdominal pain. 